\title{
INNOVATIVE TECHNOLOGIES FOR TEACHING FOREIGN LANGUAGES AT AN EARLY AGE
}

\author{
Zarina Ramazanova ${ }^{1}$, Alfiya Kitibayeva ${ }^{2}$ \\ ${ }^{1}$ E.A.Buketov Karaganda University, Karaganda, Kazakhstan \\ ${ }^{2}$ E.A.Buketov Karaganda University, Karaganda, Kazakhstan \\ ORCID ID : 0000-0002-0913-5142
}

\begin{abstract}
The article presents an analysis of the most popular innovative educational technologies used in the modern educational process. The author gives the main methodological principles and criteria that can ensure the effectiveness of the use of innovative educational technologies and improve the quality of foreign language education. The research aim is to analyze new methods of technologies in education process, particularly, in a foreign language teaching. For Generation $Z$ diversity of teaching approaches are required. Innovative technologies are intended for diversifying the methods and forms of teaching. During the study interactive technology, game technology, mobile learning and "quest" technology were examined. In addition to it, their essence and characteristics are observed.
\end{abstract}

\section{INTRODUCTION}

21st century is determined as a century of technology and digitalization [Alexandrov, 2012]. Accordingly, the generation of $21^{\text {st }}$ century is called as Generation $\mathrm{Z}$ (Gen-Z) who is the first one using the Internet and digital technology from a young age [Generation Z, 2021]. Gen-Z, mentally, physically, physiologically, including other factors, differs from any previous generations. It is really hard to surprise new generation because they can learn and search everything from the Internet. In a case in point, a teaching process of a foreign language at an early age can be provided. Therefore, teaching Gen-Z children with traditional way is insufficient.

Teachers, using only traditional approaches, have a big chance of not achieving satisfied results in a teaching activity [Arsova, 2021]. Consequently, traditional methods, in teaching foreign languages for Gen- $Z$ children, are also deficient because traditional methods might be boring and inconvenient. The significance of the usage of non-traditional methods arises from Gen- $Z$ children's preferences. Such types of methods, in general, are called as innovative technologies. Here, the term "innovation" should be determined. Based on Merriam-Webster and Cambridge dictionaries "innovation" is:

- A new idea, method, or device [Merriam-Webster, 2021];

- The act or process of introducing new ideas, devices, or methods [Merriam-Webster, 2021];

- The development of new products, designs, or ideas [Cambridge University Press, 2021].

- From provided definitions, "innovation" is the synonym of "new", and "new methods" are equivalent to "innovative technologies".

Generally, "innovative technologies" in the education means teaching and learning with the help of Internet and modern technology (smartphones, computers, interactive whiteboards, etc.) [Linde \& Petrova, 2018; Nenkov et al, 2017; ; Sushchenko, Akhmedova, Stryzhak, 2021]. Of course, just using such devices and the internet will not be reason of perfect teaching, here, the position of a teacher is important, because for young learners of a foreign language it needs to be provided qualitative information and direction.

\section{RESULTS AND DISCUSSION}

Recently, it is significant to use new technologies and methods in the process of teaching foreign languages, especially for children. Because young children might quickly become bored if a teacher always uses only traditional or old-fashioned methods during a foreign language teaching 
activity. Therefore, a teacher should always be "on trend" when it comes to teaching. Here, the word "trend" refers to the study and knowledge of new, fresh technologies and methods of teaching. For example, after the appearance of coronavirus in 2019 and, its widespread in Kazakhstan, March 13, 2020, face-to-face teaching became irrelevant and online teaching turned out to be "on trend". Furthermore, offline teaching even stopped at all in the country as the COVID-19 from epidemics became pandemics. Most teachers in Kazakhstan, who were not ready for this situation, could not fulfill online teaching requirements which led to the low level in education. As an evidence, according to the statistics of English Proficiency Index, out of 100 countries in the world, Kazakhstan ranked $92^{\text {nd }}$, adding to the list of countries with low English proficiency [informburo.kz, 2020].

As an online teaching of foreign language became popular, the process of it might be desribed by these following characteristics:

a) spatial communication between teacher and students/learners;

b) distance learning process for students/learners;

c) distance teacheing process for teacher;

d) complexity of the lesson (for example, in teaching foreign language all 4 skills: speaking, writing, listening, reading, are in one section);

e) spatial distance separation between students/learners and the institution.

During the research, some of the innovative technologies for online teaching that are relevant these days, are provided:

- Interactive technology;

- Game technology;

- Mobile learning (M-learning).

To begin with interactive technology, it is a teaching approach consisting of quick feedback from students interacting with teacher, and it helps teacher to analyze the feedback and action of a student/students fast. As an example of this innovative approach, we can provide ZOOM app which is a very popular across the world.

ZOOM is one of the leading video platforms. Besides video, in so-called platform, teachers can organize different forms of teaching a foreign language. For instance, a teacher may demonstrate his/her screen providing a presentation, virtual textbook or even some interesting videos. Also, there is a possibility of organizing some discussion and debates which are useful for improving speaking skills. Students are able to share their opinions through video-audio, zoom-chat or with a pencil that is shown in the main screen (Figure 1).

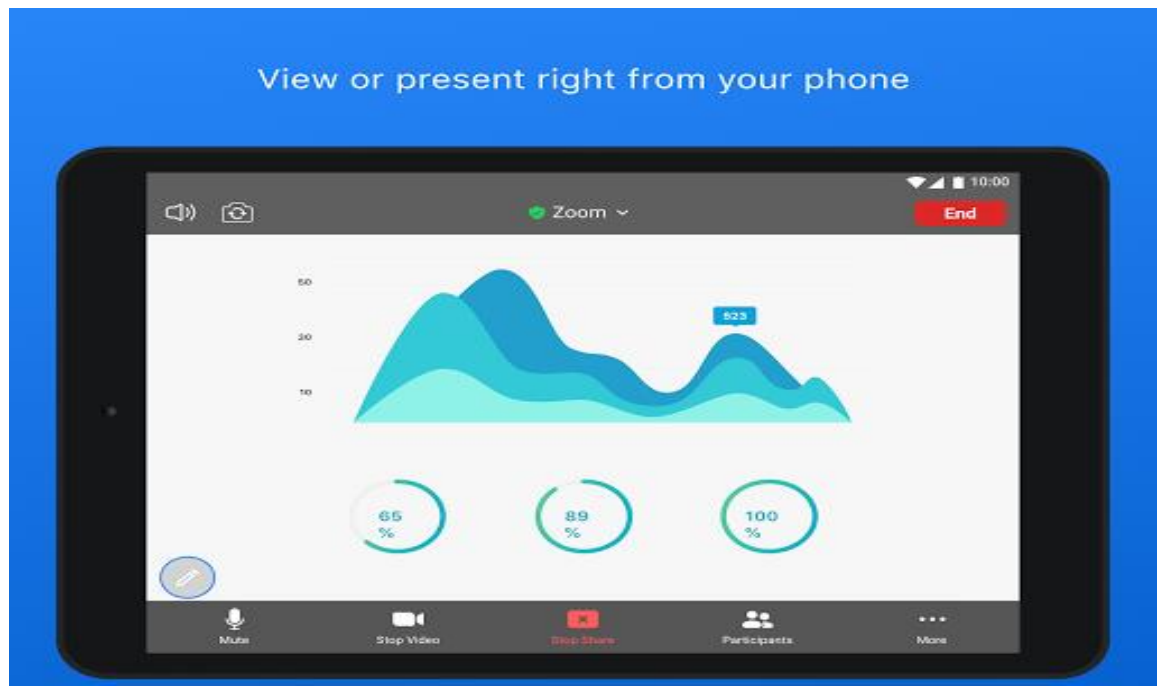

Figure 1. ZOOM platform

Note. The picture is taken from play.google.com 
Besides ZOOM, there are also some web-sites that are really useful for teachers to get a feedback as quick as possible from their learners: Kahoot!, https://miro.com/, Skype and others. Why is it important for teachers to get quick feedback from students? It is an important task during a distance teaching because comparing to offline teaching it is rather hard to observe if the students understood the whole information or not. By getting a quick response from learners, a teacher is able to get if his/her method of teaching is working or not.

Game technology. In modern days, one of the main issues in teaching a foreign language is the organization of teaching children of different age with the help of game technology. There are several factors for that. Firstly, keeping the interest of students/learners on the lesson that is being studied and strengthening their activity throughout the lesson. Secondly, it is a significant task to motivate the children and try to create a connection between real life and lesson. Lastly, in order to develop the speaking skills of students, it can be successfully carried out in the process of game activities.

There are two types of game technology: didactic and role plays/creative games. Didactic games help to develop internal linguistics of children/learners such as grammar, phonology and lexicology. The key of such a type of game is having a particular targeted result at the end of a lesson. One of the popular didactic games is "Charades" where a teacher prepares a list of words (cards) and selects a student to explain the main word without using forbidden words (Figure 2):
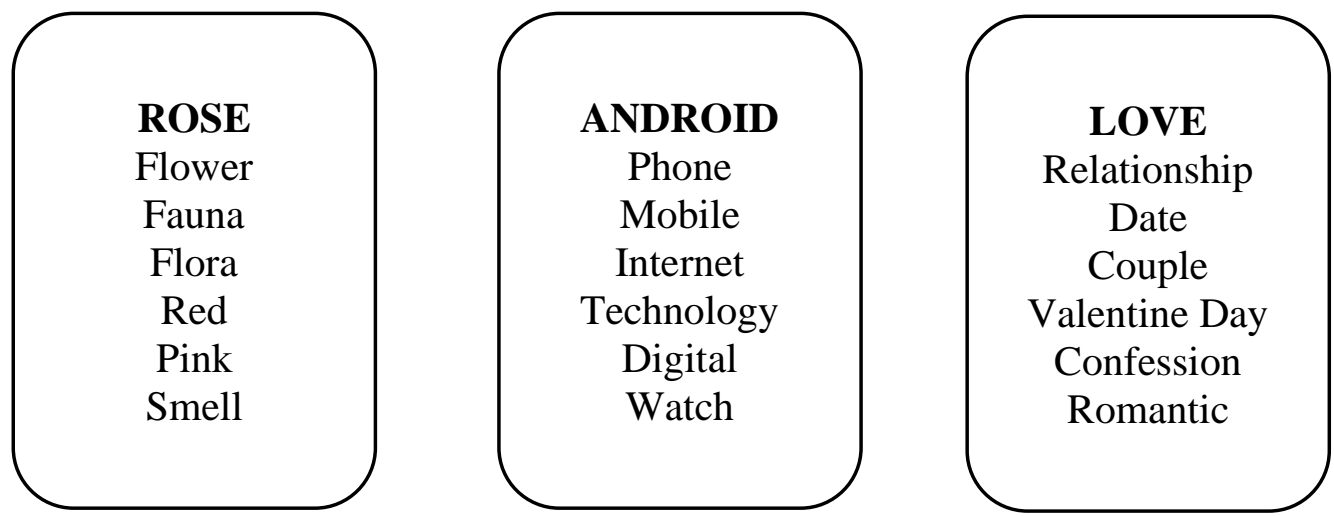

Figure 2. List of words for "Charades" game

The purpose of "Charades" game is to improve creativity and vocabulary of children. By playing this game, pupils are able to use and know synonyms of given words, and also, they will learn to explain and share their thoughts. Furthermore, even the pupils, who do not prefer to be active during the lesson, would communicate with the audience.

Role play or creative play is one effective method of improving and increasing fluency, as children have to speak according to a given situation, which leads to the usage of various communicative techniques. As for the "shy pupils", it is a great chance to have them speaking, because they can be different person and go beyond the boundaries during the role play.

Mobile learning. In $21^{\text {st }}$ century it is a complicated task to teach a foreign language for Gen$\mathrm{Z}$ pupils. Because 40 minutes (based on Kazakhstan standard) for per lesson is not enough to practice all 4 skills (listening, reading, speaking, writing). However, to solve this problem, it is suggested to use Mobile learning (M-learning). Mobile learning today is a new and evolving trend in education, characterized by the creation of a new learning environment [5]. It is better than distance or mixed learning (e-learning and traditional) as it is determined with following features:

- ensures effective independent work;

- individualizes learning;

- increases motivation;

- there is no time limit (pupils can study at any time);

- increases motivation;

- favorite interface can be selected. 
M-learning is successfully used in all disciplines, including foreign language teaching. These days, for learning a foreign language, mostly for English, there are plenty of apps in mobile market. All these apps, according to Smolova, can be divided into 3 groups:

1) mobile applications aimed primarily at improving a particular speech skill;

2) mobile applications designed to develop language skills, e.g. vocabulary or grammar;

3) universal mobile applications designed for comprehensive development of foreign language communicative competence [Smolina L.B., 2019].

Overall, the apps might be used for developing a particular skill, or for improving all four skills to learn a foreign language. For instance, to have a progress in listening skill, we recommend to use "ESL Conversation (Listening)", "6 Minute British English", "BBC Learning English", etc. These apps can be applied to develop and learn grammar, vocabulary, lexicology, slangs, idioms, and also helps to hear "native" speech and understand it.

Besides online teaching innovative technologies, there is "Quest" technology which became popular in education nowadays. In "Quest" technology there is a slight color of role play games, but the difference between them is that "Quest" technology is intended for using all tools as much as possible to solve the given task or problem.

The essence of the quest is that its participants (students, pupils) have to solve a problem that does not have an unambiguous solution, and the information sources provided are chosen so that the problem is viewed from different angles, while the information in the given sources does not provide an exact answer to the question posed. Participants in the quest should deduce from the variety of text, graphics and video material and formulate their own conclusions.

The main technique of the quest is to solve various ciphers. Here are some examples of such tasks:

- mixed letters: ghrit desi (right side), albte (table), echter (teacher), etc;

- words backwards: edisni fo xob (inside of box), txen ot wodniw (next to window), etc;

- codes in the pictures (using mirror reflection);

- puzzles;

- invisible letters, and others.

In addition to ciphers, tasks are widely used to search for objects, notes.

\section{CONCLUSIONS}

The usage of innovative technologies in education, particularly, in a teaching foreign languages differentiates the proccess of teaching which positively affects the results of educational process. However, it should be noted that this positive effect can only be achieved with careful planning of aims, outcomes and ongoing activities, all of which should be based on the educational needs and requirements of the learners. These days, there are innovative technologies such as interactive technology, game technology, M-learning and "Quest" technology. Interactive technology is about an interaction with the pupils, analyze their actions and the results of their work, offer alternative options for submitting complex educational material, i.e. for a quick feedback. Game technology contributes to the development of such qualities as independence, initiative, ability to work in a team. M-learning provides effective independent work, increases motivation and cognitive activity of students, interest in the subject, helps to individualize learning. As for "Quest" technology, it meets the needs of students, improves critical and creative thinking, develops communication in the group.

Lastly, an innovative technology, in general, includes interactivity, polymodality, multimedia, visualization of content.

\section{REFERENCES:}

Alexandrov M.O. (2012). One approach for the realization of an online poker game - Funpoker. Proceedings of IX International scientific conference "Science and Education", Kemerovo State University, Belovo Institute (branch), March 28-29, 2012, Belovo, Russia. Vol.1., pp. 124-127 
Arsova, D. (2021). Skills and competencies of the new generation of students to work with digital devices // "Innovations in technology and education": proceedings of XIV International scientific conference "Innovations in technology and education", 26 march 2021 г.: Kuzbass State Technical University, Belovo, Russia; 2021. - vol. 3., pp. 59-66 (in BG)

Cambridge University Press. (n.d.). Upcycling. In Cambridge dictionary. Retrieved October 30, 2021 https://dictionary.cambridge.org/ru/\%D1\%81\%D0\%BB\%D0\%BE\%D0\%B2\%D0\%B0\%D1\%8 0\%D1\%8C/\%D0\%B0\%D0\%BD\%D0\%B3\%D0\%BB\%D0\%B8\%D0\%B9\%D1\%81\%D0\%BA \%D0\%B8\%D0\%B9/innovation

Generation Z. (2021, June). In Wikipedia. Retrieved from https://en.wikipedia.org/wiki/Generation_Z

Kazakhstan podnialsia na odnu pozitsiiu v reitinge vledeniia angliiskim yazykom, zaniav 92-e mesto iz 100 [Kazakhstan has risen one position in the ranking of English proficiency, taking 92nd place out of 100]. (November 17, 2020). In informburo. Retrieved from https://informburo.kz/novosti/kazahstan-podnyalsya-na-odnu-poziciyu-v-reytinge-vladeniyaangliyskim-yazykom-zanyav-92-e-mesto-iz-100.html [in Russian].

Linde, I., Petrova, M. (2018) The challenges of formalization and modeling of Higher Education Institutions in the 21 st century. CBU International conference proceedings 2018: Innovations in Science and Education, 21.-23.03.2018, pp.303-308, https://doi.org/10.12955/cbup.v6.1173

Merriam-Webster. (n.d.). In Merriam-Webster.com dictionary. Retrieved October 30, 2021, from https://www.merriam-webster.com/dictionary/innovation

Nenkov, N., Dyachenko, Yu., Petrova, M., Bondarenko, G., Pustovit, V. (2017). Intelligent and Cognitive Technologies in Education of International Economic Relations Students and Human Resource Development in Enterprises: Methodology in Language. European Journal of Sustainable Development, Publisher: European Center of Sustainable Development, ISSN 22395938 (print), ISSN 2239-6101(online), http://www.ecsdev.org/, Rome, Italy, Vol 6, No.4, 2017, pp.353-360, https://doi.org/10.14207/ejsd.2017.v6n4p353

Smolina, L.B. (2019). Mobilnye prilozheniia dlia izucheniia angliiskogo yazyka kak sredstvo organizatsii samostoiatelnoi raboty obuchaiushchihsia [Mobile applications for learning English as a means of organizing independent work of students]. Retrieved from https://www.rgph.vsu.ru/ru/science/publications/docs/innov-tekh1.pdf [in Russian].

Sushchenko, O., Akhmedova, O., Stryzhak, O. (2021). The use of interactive training technologies in teaching academic disciplines for students of tourism specialities. Access to science, business, innovation in digital economy, ACCESS Press, 2(1): 28-39. https://doi.org/10.46656/access.2021.2.1(3) 